\title{
Gonadotrophin concentrations and ovulation rates in Suffolk ewes actively or passively immunized against inhibin alpha*
}

\author{
B. D. Schanbacher $\dagger$, S. R. Schemm and S. M. Rhind $\ddagger$ \\ US Department of Agriculture, Agricultural Research Service, Roman L. Hruska US Meat Animal \\ Research Center, Clay Center, Nebraska 68933-0166, USA
}

\begin{abstract}
Summary. Mature Suffolk ewes were either actively or passively immunized against the synthetic fragment of porcine inhibin alpha, pI $\alpha(1-30)$, to determine the effects on gonadotrophin secretion and ovulation rate. Thirteen control ewes were immunized against human serum albumin, 12 ewes were actively immunized against pI $\alpha(1-30)$ and 36 ewes were passively immunized with pI $\alpha(1-30)$ antiserum. Blood samples were collected at 4-h intervals for $72 \mathrm{~h}$ from oestrus-synchronized ewes following the withdrawal of the progestagen pessaries. Mean gonadotrophin concentrations measured during the oestrous cycle of control ewes, ewes actively immunized against pI $\alpha(1-30)$ and ewes passively immunized against pI $\alpha(1-30)$ were similar, but their secretory profiles differed. Serum concentrations of follicle-stimulating hormone (FSH) were highest in ewes which had received antiserum at the time of pessary withdrawal; FSH concentrations did not decrease during the follicular phase of the oestrous cycle in ewes given antiserum $24 \mathrm{~h}$ after pessary withdrawal. Subtle but significant increments in serum FSH concentrations were observed in all passively immunized ewes in which sampling commenced at the time of treatment. The amplitude of the preovulatory luteinizing hormone (LH) peak, but not of the FSH peak, and the postovulatory secondary rise in FSH were lower $(P<0.05)$ in actively immunized ewes than in control ewes. The mean $( \pm$ s.e.) ovulation rate for actively immunized ewes $(6 \cdot 6 \pm 1 \cdot 0)$ was 3 times higher $(P<0.05)$ than that for control ewes $(2 \cdot 0 \pm 0 \cdot 2)$, but was unaffected by passive immunization (range, $1 \cdot 8-2 \cdot 3$ ). The divergent results involving serum gonadotrophins and ovulation rate following active or passive immunization to the same pI $\alpha(1-30)$ immunogen suggest that changes in circulating gonadotrophins alone may not account for the increased ovulation rate in immunized Suffolk ewes.
\end{abstract}

Keywords: inhibin; fecundity; LH; FSH; immunization; sheep

\section{Introduction}

The heterodimeric glycoprotein inhibin is produced by the granulosa cells of the follicle (Henderson \& Franchimont, 1981; Schanbacher \& Ford, 1989) and is secreted into the antrum (Findlay et al., 1986) from which it has been isolated (Ling et al., 1985; Miyamoto et al., 1985; Robertson et al., 1985). Inhibin, through its feedback mechanisms on the pituitary gonadotrophs, is believed to affect follicular recruitment and ovulation rate via changes in circulating FSH (Findlay, 1986; Robertson et al., 1986). While the role of endogenous FSH remains uncertain

*Reprint requests: Reproduction Research Unit, USDA-ARS, US Meat Animal Research Center, PO Box 166, Clay Center, NE 68933-0166, USA.

†Present address: Rt. 1, Box 4A, Clay Center, Nebraska 68933, USA.

‡Present address: Macaulay Land Use Research Institute, Pentlandfield, Roslin, Midlothian EH25 9RF, UK. 
(Al-Obaidi et al., 1987; Findlay et al., 1989), active immunization of ewes against various inhibin preparations has been shown to increase ovulation rates significantly (Henderson et al., 1984; O'Shea et al., 1984; Cummins et al., 1986; Forage et al., 1987; Schanbacher, 1988a). Experiments involving passive immunoneutralization of inhibin have been reported in which acute increments in circulating FSH were observed during the follicular (Mann et al., 1990) and luteal (Mann et al., 1989) phase of the cycle or during seasonal anoestrus (Wrathall et al., 1990) following administration of inhibin antiserum. The effects of passive immunization on ovulation rate have not been characterized and the critical stage of the cycle, when immunoneutralization effects may operate, has not been identified. Our aims were, therefore, to assess (i) potential changes in serum gonadotrophins following inhibin immunoneutralization at 3 specific times prior to the ensuing ovulation and (ii) ovulation rate in Suffolk ewes actively or passively immunized against a specific fragment of the inhibin alpha subunit.

\section{Materials and Methods}

Animals and experimental design. Sixty-one Suffolk ewes with a mean weight of $80 \mathrm{~kg}(\mathrm{~s} . \mathrm{e} . \mathrm{m} .=1 \cdot 1)$ were randomly assigned to one of 5 treatment groups in September. Twelve ewes, previously actively immunized (AImm) against a synthetic peptide corresponding to the $N$-terminal sequence (1-29) of the porcine inhibin alpha subunit with tyrosine added to the carboxy-terminus, pIa(1-30), were assigned to the first group (Schanbacher, 1988a). Two booster injections on 26 September and 24 October were administered subcutaneously to these ewes to induce pI $\alpha(1-30)$ antibody titres at the time of the study in November. A second group ( $C ; n=13)$ was immunized against human serum albumin (hSA) and served as controls while the remaining 3 groups were passively immunized at different times during the oestrous cycle with a high titre pI $\alpha(1-30)$ antiserum pool produced in rams. Oestrus was synchronized in all ewes using intravaginal progestagen pessaries ( $20 \mathrm{mg}$ fluorogestone acetate; Searle Synchromate) inserted for 14 days starting on 24 October. On Day 10 after pessary insertion (i.e. $96 \mathrm{~h}$ before pessary removal), ewes were injected (i.v.) with $1 \mathrm{ml}$ of $\mathrm{pI} \alpha(1-30)$ antiserum $/ \mathrm{kg}$ body weight $(\mathrm{PImm}-96 ; n=12)$. Two other groups of ewes received the same dose of antiserum when (Day 14) pessaries were withdrawn from all ewes (PImm $0 ; n=12$ ) and at $24 \mathrm{~h}$ after pessary withdrawal (PImm $+24 ; n=12)$. Control ewes receiving nonimmune serum were not included in this trial since previous investigations at this laboratory involving ewes administered large i.v. doses of nonimmune ram serum observed no acute changes in circulating gonadotrophin concentrations (B. D. Schanbacher, unpublished data). Blood samples were collected from all ewes by jugular venepuncture at 4-h intervals for $72 \mathrm{~h}$ starting at the time of pessary withdrawal ( 7 November). All serum samples were assayed for luteinizing hormone (LH) and FSH concentrations and pI $\alpha(1-30)$ antibody titres. Ten days after pessary withdrawal, all 61 ewes were laparoscoped and the number of corpora lutea was recorded.

pIa (1-30) immunogen and antisera. The pI (1-30) synthetic peptide was conjugated to hSA by the glutaraldehyde reaction as described by Schanbacher $(1988 \mathrm{a}, \mathrm{b})$. Sufficient conjugate was prepared at the beginning of the study for immunizations for each of 12 ewes $(167 \mu \mathrm{g}$ pla(1-30) equivalent/ewe). The conjugate was dissolved in $0.5 \mathrm{ml}$ phosphate-buffered saline (PBS), emulsified in an equal volume of Freund's complete (primary) or incomplete (booster) adjuvant and injected subcutaneously on the abdomen of each ewe.

The pla(1-30) antiserum collected from 4 immunized rams was sterile-filtered $(0 \cdot 2 \mu \mathrm{m})$ and pooled and the antibiotic Penstrep $(0 \cdot 1 \%$ : Durvet, Inc., Blue Springs, MO, USA) was added. The pool contained high antibody titre ( $70 \%$ binding at $1: 10000$ dilution) to the radioiodinated ligand, pl $\alpha(1-30)$. This antiserum was specific to the inhibin alpha subunit and did not cross-react with gonadotrophin-releasing hormone (GnRH), LH, FSH, growth hormone $(\mathrm{GH})$, prolactin (PRL), epidermal growth factor or transforming growth factor- $\beta$. Verification of specific binding and immunoneutralization of endogenous inhibin would be preferable, but native inhibin was not available as ligand for testing in this laboratory. We believe that antisera to this subunit ligand has the potential to neutralize native inhibin in view of the suitability of this antisera as a measure of physiological changes in circulating inhibin concentrations (Schanbacher, 1988b). All antibody titres were determined by dilution of sera in PBS, overnight incubation with $\sim 20000$ c.p.m. of radioiodinated pl $\alpha(1-30)$ and ethanol precipitation (Schanbacher, 1988b). Background binding to hSA-immunized ewe sera or nonimmune sera was $<2 \%$.

Hormone assays. LH values were determined in $200-\mu 1$ duplicate serum samples by a previously described radioimmunoassay (Schanbacher \& Ford, 1976). The assay uses an anti-ovine LH serum (DJB 3-1211) and NIH LH S18 as reference standard. Assay sensitivity was $0.5 \mathrm{ng} / \mathrm{ml}$ and the intra- and interassay coefficients of variation were 7 and $9 \%$, respectively.

FSH concentrations were quantified in $200-\mu \mathrm{l}$ duplicate serum samples by double-antibody radioimmunoassay (Schanbacher, 1988b). The assay uses an anti-ovine FSH serum (JAD 17-679) and NIH FSH S10 as reference standard. Assay sensitivity was $3 \mathrm{ng} / \mathrm{ml}$ and the intra- and interassay coefficients of variation were 7 and $11 \%$, respectively.

Statistical analysis. Means for antibody titres, serum concentrations of LH and FSH and ovulation responses to active and passive immunization to pI $\alpha(1-30)$ were compared by analyses of variance techniques with differences 
between treatment means determined by Student-Newman-Keuls multiple range test. Changes in serum FSH during the follicular phase of the oestrous cycle were also assessed by regression analysis procedures. Regression equations of FSH values $36 \mathrm{~h}$ prior to the LH surge were evaluated and their respective slopes compared for possible treatment effects.

\section{Results}

AImm ewes achieved a specific binding titre of $72 \%(1: 1000)$ at the time of pessary withdrawal and blood sampling. This titre was an order of magnitude higher than that achieved by passive immunization (Table 1). Although variation existed between ewes for body weight, administration of $\mathrm{pI} \alpha(1-30)$ antiserum at $1 \mathrm{ml} / \mathrm{kg}$ body weight resulted in comparable titres in all passively immunized ewes. The slightly lower titres achieved at pessary withdrawal in PImm -96 ewes compared with subsequent titres in PImm 0 and PImm +24 ewes appeared to be due to the decay in titre between Days 10 and 14 of the pessary treatment. During the blood sampling period, titres did not change in AImm ewes. Antibody titres decreased $\sim 6$ percentage points for PImm -96 and PImm 0 ewes and 3 percentage points for PImm +24 ewes over the respective blood sampling period. Antibody titres were not detectable in $\mathrm{C}$ ewes.

Table 1. Mean antibody titres, luteinizing hormone (LH) and follicle-stimulating hormone (FSH) concentrations in Suffolk ewes and ovulation response to active immunization against human serum albumin (control) or the synthetic fragment of porcine inhibin alpha $(\mathrm{pI} \alpha(1-30))(\mathrm{AImm})$ or passive immunization against $\mathrm{pI} \alpha(1-30)$ at $96 \mathrm{~h}$ before (PImm -96), synchronous with (PImm 0), or $24 \mathrm{~h}$ after (PImm + 24) removal of progestagen pessaries

\begin{tabular}{lccccc}
\hline Treatment & $n$ & $\begin{array}{c}\text { Anti-pI } \alpha(1-30) \text { titre } \\
\text { (\% binding) }\end{array}$ & $\begin{array}{c}\text { Serum LH } \\
(\mathrm{ng} / \mathrm{ml})\end{array}$ & $\begin{array}{c}\text { Serum FSH } \\
(\mathrm{ng} / \mathrm{ml})\end{array}$ & $\begin{array}{c}\text { No. of } \\
\text { corpora lutea }\end{array}$ \\
\hline Control & 13 & $<2(1: 100)$ & $2 \cdot 6 \pm 0 \cdot 2$ & $61 \cdot 6 \pm 2 \cdot 6$ & $2 \cdot 0 \pm 0 \cdot 2$ \\
AImm & 12 & $72(1: 1000)$ & $2 \cdot 9 \pm 0 \cdot 1$ & $64 \cdot 9 \pm 2 \cdot 8$ & $6 \cdot 6 \pm 1 \cdot 0^{*}$ \\
PImm -96h & 12 & $70(1: 100)$ & $3 \cdot 0 \pm 0 \cdot 5$ & $59 \cdot 7 \pm 2 \cdot 8$ & $2 \cdot 3 \pm 0 \cdot 2$ \\
PImm 0 & 12 & $78(1: 100)$ & $4 \cdot 6 \pm 0 \cdot 2^{*}$ & $96 \cdot 1 \pm 5 \cdot 2^{*}$ & $1 \cdot 8 \pm 0 \cdot 3$ \\
PImm +24h & 12 & $79(1: 100)$ & $3 \cdot 3 \pm 0 \cdot 2$ & $56 \cdot 3 \pm 0 \cdot 8$ & $2 \cdot 2 \pm 0 \cdot 1$ \\
\hline
\end{tabular}

*Significantly different from control values, $P<0.05$.

The LH and FSH profiles for all ewes were retrospectively standardized about the preovulatory LH peak and sequential mean values graphically depicted for AImm and C ewes (Fig. 1) and for passively immunized ewes (Fig. 2). Mean serum gonadotrophin concentrations during the follicular phase of the oestrous cycle (i.e. before the LH surge) are presented for the respective treatment groups in Table 1. Although variable among ewes, the mean interval between pessary withdrawal and onset of the LH surge ( $48 \pm 4 \mathrm{~h}$ ) was statistically similar for ewes in the various treatment groups. LH and FSH means did not differ between C and AImm ewes, or between C and PImm -96 or PImm +24 ewes. Serum LH and FSH concentrations were higher than controls $(P<0.05)$ only when antiserum was administered at pessary withdrawal. Treatment did not affect the timing of the LH surge. Amplitude of the LH surge was comparable for C, PImm -96 and PImm 0 ewes but was reduced $(P<0.05)$ for AImm and PImm +24 ewes. The amplitude of the ovulatory surge of FSH did not differ between treatment groups. The magnitude of the postovulatory rise in FSH was lower $(P<0.05)$ in AImm ewes $(48 \pm 2 \mathrm{ng} / \mathrm{ml}$; mean \pm s.e.m. $)$ than in all other treatment groups in which the mean values were comparable $(74 \pm 7 \mathrm{ng} / \mathrm{ml}$; mean \pm s.e.m.).

Analyses of serum FSH concentrations during the follicular phase of the oestrous cycle indicated a decline in FSH for $\sim 36 \mathrm{~h}$ before onset of the LH surge in C, AImm, PImm -96 and PImm 0 ewes (follicular-phase LH concentrations did not differ). FSH concentrations decreased by an average of $30 \%$ from maximum values observed at pessary withdrawal; they did not decrease 


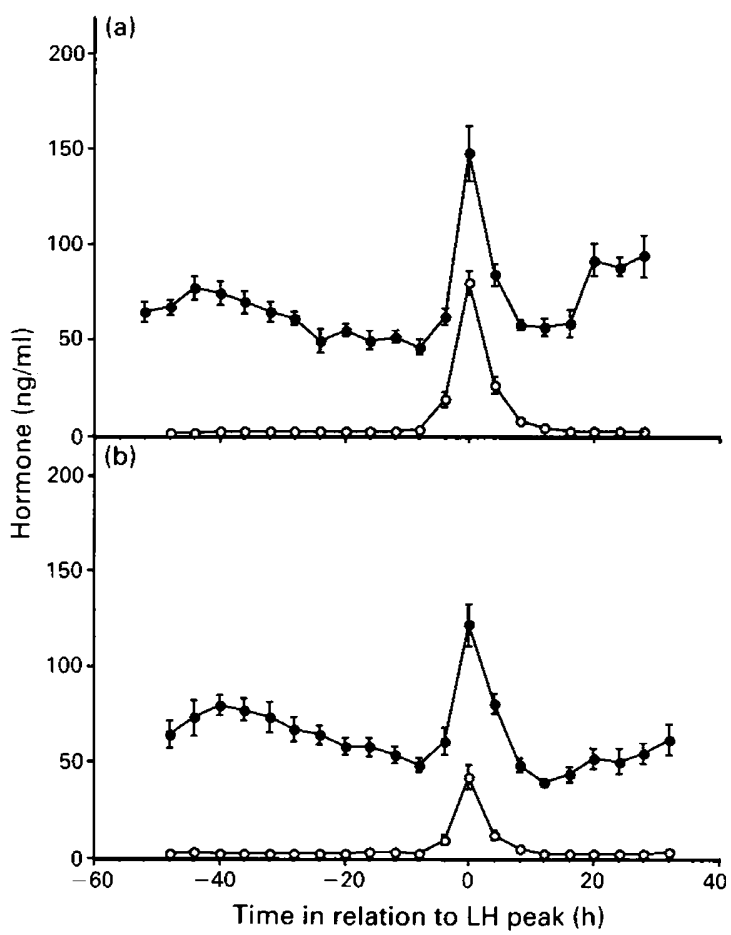

Fig. 1. Mean serum luteinizing hormone ( $\mathrm{LH}, \mathrm{O})$ and follicle-stimulating hormone (FSH, concentrations during the follicular phase of the oestrous cycle in ewes actively immunized against (a) hSA (control); or (b) inhibin alpha pI $\alpha(1-30)$ (AImm). Profiles were synchronized about the preovulatory LH surge.

during the follicular phase in ewes administered antiserum $24 \mathrm{~h}$ after pessary withdrawal (PImm +24 ewes). The number of corpora lutea in AImm ewes was 3 times higher than that of $\mathrm{C}$ ewes (Table 1) whereas the number for passively immunized ewes was unaffected.

\section{Discussion}

The results of this study confirmed previous findings (Schanbacher, 1988a) that active immunization of Suffolk ewes against the synthetic fragment of porcine inhibin alpha results in specific antibodies to the peptide and increased ovulation rate with little or no change in mean serum FSH concentrations. Immunoneutralization of inhibin should theoretically increase serum FSH (Al-Obaidi $e t$ al., 1987; Mann et al., 1989, 1990; Wrathall et al., 1990). However, no changes were observed during the follicular phase of the progestagen-synchronized cycle of AImm ewes relative to controls. Mean FSH concentration was, however, lower during the early postovulatory period in these ewes. The antibody titre achieved was slightly higher in this study than in our earlier report with mature Suffolk ewes given the same immunogen (72\% vs. 39\% at 1:1000 dilution; Schanbacher, 1988a) and so was the observed ovulation rate (6.6 vs. 3.9 corpora lutea).

Intravenous administration of high titre antibody was a convenient and controlled means of immunoneutralizing circulating inhibin in ewes. This approach to passive immunity produced predictable antibody titres in the recipient ewes and, because of its relatively long half-life, the titres were effectively maintained through the period of follicular recruitment and ovulation. The reason that the gonadotrophin concentrations were not affected in the AImm ewes, which had an increased ovulation rate, remains uncertain. This may have been the result of a transient increase in 


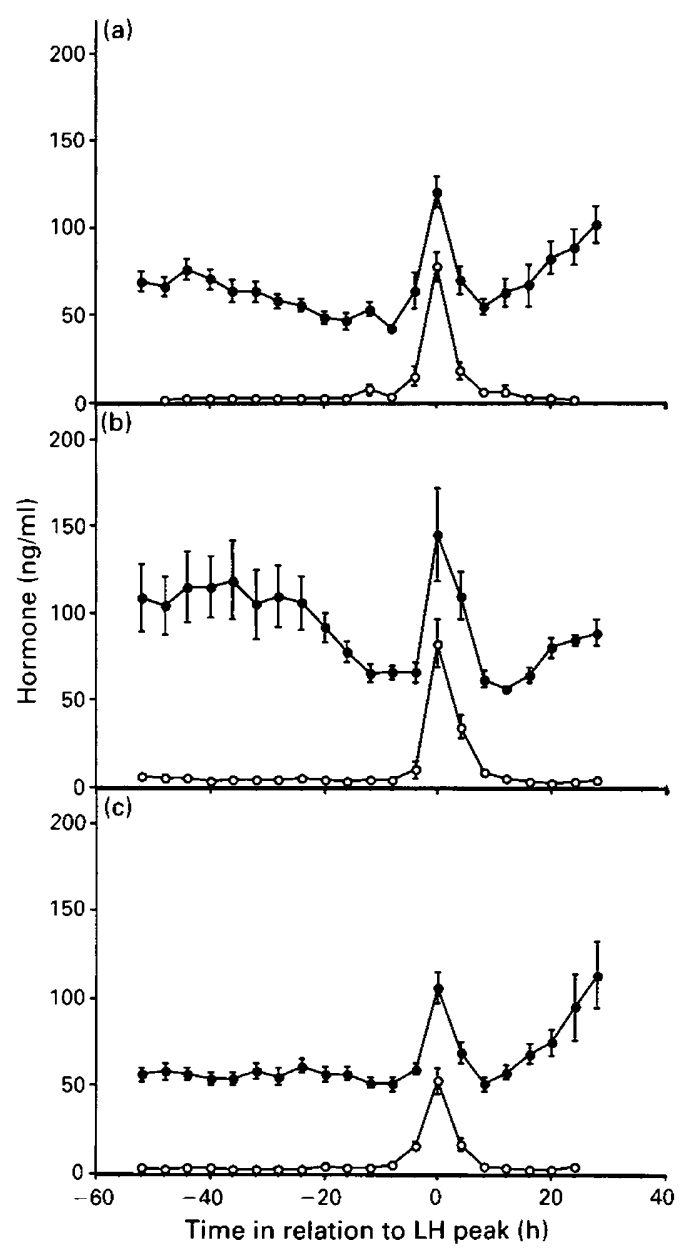

Fig. 2. Mean serum luteinizing hormone $(\mathrm{LH}, \mathrm{O})$ and follicle-stimulating hormone (FSH, concentrations during the follicular phase of the oestrous cycle in ewes passively immunized with inhibin alpha pIa(1-30) antiserum at (a) $96 \mathrm{~h}$ before (PImm -96), (b) the time of (PImm 0) or (c) $24 \mathrm{~h}$ after pessary removal $(\mathrm{PImm}+24)$. Profiles were synchronized about the preovulatory LH surge.

FSH at the time of immunization so that, at blood sampling, a new equilibrium between FSH and inhibin was established.

The lower antibody titres observed in PImm -96 and PImm +24 ewes, compared with AImm ewes, may explain the lack of effect on serum gonadotrophin concentrations and ovulation rates, but does not explain the discrepancy between higher gonadotrophin concentrations and normal ovulation rates of PImm 0 ewes compared with C, PImm -96 and PImm +24 ewes. Although response to passive immunity may depend on the timing of antiserum treatment and the stage of oestrous cycle, our results suggest that the time of blood sampling relative to treatment is critical for observing changes in FSH secretion. Mann et al. (1989) reported a transient rise in plasma FSH 5-9 h after intravenous injection of inhibin antiserum into Scottish Blackface ewes on Day 8 of the luteal phase of the oestrous cycle; associated changes in plasma LH concentrations were not found. In view of the delayed and transient increase in FSH reported by Mann et al. (1989) following passive immunization against inhibin, the positive FSH response in the PImm 0 ewes of the present study and the absence of any decline in FSH following antiserum treatment of PImm 
+24 ewes, we suggest that passive immunization with pI $\alpha(1-30)$ antiserum can be an effective modulator of FSH secretion and that such an effect is likely to be observed if treatment and blood sampling are properly timed. This explanation accommodates the observations of the present study with respect to PImm +24 ewes; unfortunately, blood samples were not collected for PImm -96 ewes between the time of antiserum administration (Day 10) and pessary withdrawal (Day 14) so possible changes in FSH concentration during this time were not recorded. Although our study and that of Mann et al. (1989) used a similar synthetic oligopeptide representing the $N$-terminus of the porcine inhibin alpha subunit, our results are not directly comparable because we obtained at least $70 \%$ binding in sera diluted 1:100 whereas they reported lower titres in sera diluted 1:15. Secondly, because of an insufficient number of ewes in the Mann et al. (1989) study, treatment effects on ovulation rate are difficult to assess. Wrathall et al. (1990), using Suffolk crossbred ewes, demonstrated that passive immunization of seasonally anoestrous ewes with an antiserum made against the tyrosine-substituted, 30-amino-acid, $N$-terminus of the bovine inhibin alpha subunit, bI $\alpha(1-30)$, provoked a rapid, dose-dependent increase in plasma FSH concentrations which lasted up to $30 \mathrm{~h}$. Plasma LH concentrations were not affected by antiserum treatment.

Actively and passively immunized ewes exhibited normal oestrus and ovulation based on the presence of corpora lutea at Day 8 of the oestrous cycle. The reduced amplitude of the ovulatory $\mathrm{LH}$ peak, but not the FSH peak, in AImm ewes is noteworthy since mean serum LH concentration was unaffected in this group and inhibin feedback on the pituitary is supposedly restricted to FSH. Since pituitary $\mathrm{LH}$ release in response to exogenous $\mathrm{GnRH}$ is compromised in ewes actively immunized against inhibin (Wrathall et al., 1990), we conclude that inhibin effects on gonadotrophin release are not restricted to $\mathrm{FSH}$, but involve subtle changes in $\mathrm{LH}$ release. Our observation that both $\mathrm{LH}$ and FSH can increase following passive immunization to inhibin (PImm 0 ewes) supports this conclusion. Lastly, we recognize the intricate feedback relationships between gonadotrophins, inhibin and oestrogens and the possibility that our results may be complicated by immunization-induced changes in oestradiol secretion. These interactions remain the subject of future investigations.

In summary, increased ovulation rates in Suffolk ewes, actively immunized against the inhibin alpha fragment pI $\alpha(1-30)$, without changes in serum LH or FSH during the follicular phase of the oestrous cycle are reported. The amplitude of the ovulatory increase in LH was compromised by active immunization, but the postovulatory, secondary rise in FSH was attenuated. FSH secretory pattern, but not ovulation rate, was influenced by passive immunization to pI $\alpha(1-30)$. Divergent results involving serum gonadotrophins and ovulation rate following active or passive immunization to the same pl $\alpha(1-30)$ immunogen suggest that changes in circulatory gonadotrophins alone do not explain changes in ovulation rates in immunized Suffolk ewes.

We thank N. Ling for $\left[\mathrm{Tyr}^{30}\right]$ pl $\alpha(1-30)$, J. Dias for FSH antiserum, D. Bolt for LH antiserum and the National Hormone and Pituitary Program of NIAMDD for radio-iodination grade FSH. Special thanks are given to R. Shaw, J. Overy and L. Peshek for technical assistance and to L. Parnell for preparation of the manuscript.

Mention of a trade name, proprietary product or specific equipment does not constitute a guarantee or warranty of the product by the US Department of Agriculture and does not imply its approval to the exclusion of other products that may also be suitable.

\section{References}

Al-Obaidi, S.A.R., Bindon, B.M., Findlay, J.K., Hillard, M.A. \& O'Shea, T. (1987) Plasma follicle stimulating hormone in Merino ewes immunized with an inhibinenriched fraction from bovine follicular fluid. Anim. Reprod. Sci. 14, 39-51.

Cummins, L.J., O'Shea, T., Al-Obaidi, S.A.R., Bindon, B.M. \& Findlay, J.K. (1986) Increase in ovulation rate after immunization of Merino ewes with a frac- tion of bovine follicular fluid containing inhibin activity. $J$. Reprod. Fert. 77, 365-372.

Findlay, J.K. (1986) The nature of inhibin and its use in the regulation of fertility and diagnosis of infertility. Fertil. Steril. 46, 770-776.

Findlay, J.K., Doughton, B., Robertson, D.M. \& Forage, R.G. (1989) Effect of immunization against recombinant bovine inhibin $\alpha$ subunit on circulating 
concentrations of gonadotrophins in ewes. J. Endocr. 120, 59-65.

Findlay, J.K., Tsonis, C.G., Staples, L.D. \& Cahill, R.N.P. (1986) Inhibin secretion by the sheep ovary. $J$. Reprod. Fert. 76, 751-761.

Forage, R.G., Brown, R.W., Oliver, K.J., Atrache, B.T., Devine, P.L., Hudson, G.C., Goss, N.H., Bertram, K.C., Tolstochev, P., Robertson, D.M., de Kretser, D.M., Doughton, B., Burger, H.G. \& Findlay, J.K. (1987) Immunization against an inhibin subunit produced by recombinant DNA techniques results in increased ovulation rate in sheep. $J$. Endocr. 114, R1-R4.

Henderson, K.M. \& Franchimont, P. (1981) Regulation of inhibin production by bovine ovarian cells. $J$. Reprod. Fert. 63, 431-442.

Henderson, K.M., Franchimont, P., Lecomte-Yerna, M.J., Hudson, N. \&.Ball, K. (1984) Increase in ovulation rate after active immunization of sheep with inhibin partially purified with bovine follicular fluid. J. Endocr. 102, 305-309.

Ling, N., Ying, S.-Y., Ueno, N., Esch, F., Denoroy, L. \& Guillemin, R. (1985) Isolation and partial characterization of a $\mathrm{M}_{t} 32000$ protein with inhibin activity from porcine follicular fluid. Proc. Natl Acad. Sci. 82, 7217-7221.

Mann, G.E., Campbell, B.K., McNeilly, A.S. \& Baird, D.T. (1989) Passively immunizing ewes against inhibin during the luteal phase of the oestrous cycle raises the plasma concentration of FSH. $J$. Endocr. 123, 383-391.

Mann, G.E., Campbell, B.K., McNeilly, A.S. \& Baird, D.T. (1990) Effects of passively immunizing ewes against inhibin and oestradiol during the follicular phase of the oestrous cycle $J$. Endocr. 125, 417-424.

Miyamoto, K., Hasegawa, Y., Fukuda, M., Nomura, M., Igarashi, M., Kangawa, K. \& Matsuo, H. (1985) Isolation of porcine follicular fluid inhibin of $32 \mathrm{~K}$ daltons. Biochem. Biophys. Res. Commun. 129, $396-403$.
O'Shea, T., Al-Obaidi, S.A.R., Bindon, B.M., Cummins, L.J., Findlay, J.K. \& Hillard, M.A. (1984) Increased ovulation rate in Merino ewes and advancement of puberty in Merino lambs immunized with a preparation enriched in inhibin. In Reproduction in Sheep, pp. 335-337. Eds D. R. Lindsay \& D. T. Pearce. Australian Academy of Sciences, Canberra.

Robertson, D.M., de Vos, F.L., Foulds, L.M., Burger, H.G., Morgan, F.J., Hearn, M.T.W. \& de Kretser, D.M. (1986) Isolation of a $31 \mathrm{kDa}$ form of inhibin from bovine follicular fluid. Mol. cell. Endocr. 44, $271-277$.

Robertson, D.M., Foulds, L.M., Leversha, L., Morgan, F.J., Hearn, M.T.W., Burger, H.G., Wettenhall, R.E.H. \& de Kretser, D.M. (1985) Isolation of inhibin from bovine follicular fluid. Biochem. Biophys. Res. Commun. 126, 220-226.

Schanbacher, B.D. (1988a) Increased ovulatory response of Suffolk ewes vaccinated against a synthetic fragment of porcine inhibin. Biol. Reprod. 38 (Suppl. 1), 62.

Schanbacher, B.D. (1988b) Radioimmunoassay of inhibin: Serum responses to unilateral and bilateral orchidectomy. Endocrinology 123, 2323-2330.

Schanbacher, B.D. \& Ford, J.J. (1976) Seasonal profiles of plasma luteinizing hormone, testosterone and estradiol in the ram. Endocrinology 99, 752-757.

Schanbacher, B.D. \& Ford, J.J. (1989) Follicle-stimulating hormone stimulated inhibin production from porcine granulosa cells in vitro. J. Anim. Sci. 67 (Suppl. 2), 135.

Wrathall, J.H.M., McLeod, B.J., Glencross, R.G., Beard, A.J. \& Knight, P.G. (1990) Inhibin immunoneutralization by antibodies raised against synthetic peptide sequences of inhibin $\alpha$ subunit: Effects on gonadotrophin concentrations and ovulation rate in sheep. J. Endocr. 124, 167-176.

Received 28 August 1990 